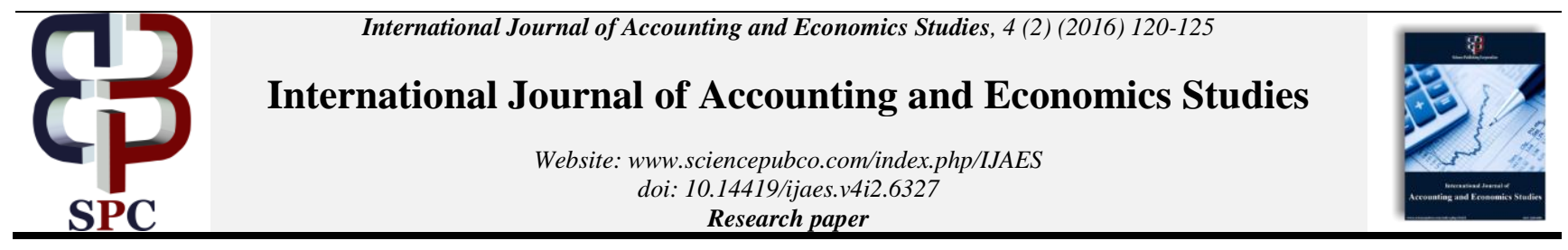

\title{
Review and ranking the private insurance companies in Iran based on TOPSIS model
}

\author{
Leila Asadi *, Ali Esmaeilzadeh Moghri \\ Department of Accounting, Islamshahr Branch, Islamic Azad University, Islamshahr, Iran \\ *Corresponding author E-mail: leilaasadi60@yahoo.com
}

\begin{abstract}
Insurance companies are the most important economic institutions in each country and they support other economic entities. Their proper performance play an important role in the booming the economy. Insurance companies to achieve effective and strong performance should be familiar with performance of competitors and themselves and according to their information take necessary measures. For this purpose, the current study aims to rank the private insurance companies. In this regard, financial and non-financial indicators as well as performance index for 17 private insurance companies are extracted over 4 years (2011 to 2014) based on their financial statements. The weight of each index was determined using the Shannon entropy. Then, insurance companies were ranked using TOPSIS. The results showed that based on financial indicators, Arman insurance company in 2011 and 2012 had the optimal performance from the standpoint of the criteria (1st). In the years, 2013 and 2014 Kosar insurance Company and Mihan insurance companies were at the 1st place. In addition, Alborz insurance Company had a good performance in terms of performance indexes in 2011 and 2013, (1st). In the years 2012 and 2014, Parsian and Pasargad Insurance Companies ranked 1st. Based on non-financial indicators, Asia insurance company in the period under review (2011 to 2014) ranked in the first place.
\end{abstract}

Keywords: Ranking; Insurance; Financial and Non-Financial Indicators; TOPSIS; Performance Evaluation Indexes.

\section{Introduction}

Today, most organizations are operating in a dynamic and competitive environment; an environment that variables are constantly changing and the possibility of predicting these changes is difficult. In addition, organizations to achieve their goals spend a lot and a lot of time and cost. Therefore, knowledge of how organizations function in order to achieve the objectives and understanding of the situation in today's complex and dynamic environment is very important for managers (Hassanzadeh and Zare, 2009). Currently, the insurance industry is one of the most important economic institutions in each country and are of important supporting institutions of other economic institutions and households. The successful performance of the industry is an incentive for other industries and economic development of the country. Insurance companies to achieve effective and strong performance should be familiar with performance of competitors and themselves and according to their information take necessary measures. Performance evaluation is the tool to gain this information and knowledge. In other words, by performance evaluation management can be informed of the implementation of the objectives and operations to the follow-up and, if necessary, measure and modify them. The insurance industry is among the industries that is very important in the new economy and domestic and foreign trade. Performance evaluation and ranking of insurance companies in addition to defining the overall position of firms in the industry and market and informing the stakeholders, increases competition and dynamics of industry and development of community. Ranking of insurance companies is one of the most common methods of evaluating the performance and one of the most important tools to determine the strengths and weaknesses and identify the opportunities and external threats. Insurance institutions pay great importance for ranking. Because ranking determines the market capacity about the financial strength and ability to carry liability toward insurers, and affects the competitive position of the institutions. Achieved high rank, is a very important factor in advertising, branding and good reputation among consumers or investors, brokers and insurance agents. In addition, the macro view, ranking help market efficiency because ranking is considered as one of the elements of non-price competition. Consumers benefit from competition and they choose to buy insurance products in a more transparent market from more suitable company according to their need (Mirzaee and Safari, 2009).

Identifying performance evaluation and ranking of insurance companies is important for several groups. 1-watchers 2. Shareholders 3. Representatives 4. Reinsurers 5.Insurers. However, the main objective of evaluating the performance of insurance companies is the protection of insurers. However, how this assurance is achieved and in what manner customers are informed is important. One of the most common ways to evaluate the performance of insurance companies is to rank them. Of course, validation and ranking should also be made by the prestigious and well-known institutions to have reliability. Due to sanctions, it was not possible Iranian insurance companies to get international ranking of international companies. That's why the insurer in the insurance market of the country, is selected not based on the ratings received but by relying on advertising marketing companies and bidding done by large insurers. The tender for the selection of insurer is based on the insurer's minimum rates; also due to the lack of ranking, activity of Iranian insurance companies in international markets and reinsurance is very limited. While international rating 
agencies refuse to provide services to Iranian insurance companies, it is necessary an institution like the Central Insurance of Iran as the ruling and governing center for insurance operations in Iran design and deploy a rating system and assess the financial ability of insurance companies in fulfillment of their obligations (Soleimani, 2011).

Currently, the insurance industry is facing lack of assessment Iran. Rating assessment can certainly lead more transparency in the market competition and consumer protection. However, it is clear that the underlying global problem is the lack of ranking for Iranian insurance institutions. (Mirzaee and Safari, 2009). As a result, the lack in the ranking of insurance companies and the lack of measures to do ranking of insurance companies, made the researcher to examine and rank private insurance companies in Iran based on TOPSIS using financial and non-financial criteria and performance evaluation criteria. The aim of the present study is ranking of private insurance companies in Iran based on TOPSIS using financial and non- financial indicators and performance evaluation criteria.

\section{Review of related literature}

So far, several studies have been conducted to evaluate the performance and rate insurance companies. Omrani et al (2014), in their study reviewed a hybrid model for evaluating performance and ranking of insurance companies using expert opinions. In their research hybrid model based on hierarchical methods of analysis, principal component analysis and data envelopment analysis was offered to evaluate the performance by insurance companies in Iran. Using it, fourteen insurance company were ranked with thirteen standard index. The results showed that Dana, Razi and Day insurance companies, respectively ranked first to third. Nemati and Kazemi (2014), in their study reviewed the ratings of insurance companies using their multi-criteria decision-making methods. In this study, the performance of insurance companies in Iran during the years 2008, 2009 and 2010 have been evaluated. The weight of each index was determined using the Shannon entropy. Then, insurance companies were ranked using four different methods. The results of the various methods were mixed using the Copeland. The results showed that Iran Insurance company had the best performance over the years. Dehkordi (2014) in his study evaluated and ranked the factors affecting the financial performance of the insurance industry with (DEA / MADM). The aim of this study was to evaluate and rank the factors affecting the financial performance of the insurance industry using fuzzy VIKOR approach and then evaluate and rank 23 financial insurance companies using data envelopment analysis. The results of this study not only help the directors of the company, but also help economic officials as well as policyholders to identify efficient and inefficient firms. Also according to the analysis conducted in the context of firm performance, inefficient companies' development to achieve the specified performance levels is determined. Mazloumi and Dadvand, (2012), in their study identified and ranked the af fective factors of insurance companies to achieve competitive advantage. In this article, Hill and Jones model - which focused on the internal factors, is used as the main framework. This model consists of four dimensions including efficiency, quality, innovation and responsiveness to customer. In order to identify indicators of each dimension of the research literature of study was reviewed which finally by industry expert opinion, 13 indicators were identified as influential factors. In the second stage with opinion of the top managers of insurance companies, ranking of the dimensions and indexes were done by ANP. According to senior managersm, meeting customer needs is the first priority, and quality, efficiency and innovation are the next priorities to achieve a competitive advantage. Hosseini et al (2011), in his study, compared the ranking of top companies based on financial ratios combined with AHP-TOPSIS approach and Tehran's Stock Exchange Indexes. In this study, fifty top companies referred by Tehran Stock Exchange during the 2008.2009, and 2010 using AHP-TOPSIS hybrid ap- proach, and based on four financial ratios (liquidity, activity, leverage and profitability) were ranked and then were compared with the ranking based on indicators and parameters of the Stock Exchange. The results indicated the existence of an inverse relationship and relatively weak correlation in 2008 and a direct relationship in the years 2009 and 2010 based on financial ratios using a hybrid approach of AHP-TOPSIS and Stock Exchange. This means that on the contrary, firms with a higher rank in stock ratings were not in a much higher positions, based on financial ratios. Parizadi (2009) in his study entitled financial ratios and economic variables affecting evaluation, health and the financial stability of insurance companies, has proposed 5 overall factors including capital adequacy and leverage ratios, profitability ratios, liquidity ratios and operating ratios and risk-taking and other basic criteria as criteria for health and financial stability of 13 Insurance Companies in Iran. He used real data extracted from financial statements of insurance companies, including balance sheets, profit and loss statements and cash flow statements and ratios and selected variables and using appropriate techniques to see similarities and compliance assessed the financial health of insurance companies, and ultimately ranked them.

Sehat et al (2015), in their study, evaluated the ranking of insurance companies in Iran using AHP and TOPSIS techniques. The results showed that insurance companies were ranked respectively as follows: Iran Insurance Company, Asia, Pasargad, Day, Moallem, Karafarin and Parsian. Results presented had better performance and can be used in future research with a larger population. Ak Hisar and Tunay (2015) in their study, reviewed the evaluation and ranking of insurance companies in Turkey with AHP and TOPSIS methods. The results showed that AHP and TOPSIS models are suitable methods for ranking firms and companies can use these models to develop their strategies. Khodayi and Ferdowsi Nejad (2013) in their study reviewed and rated the insurance companies using hierarchical analysis and factor analysis. They ranked insurance companies checking the quality of assets, the quality of cash flow, earnings quality and capital adequacy. Result of ranking is as follows: Dana, Aborz, Novin, Sina, Saman, Tosee, Parsian, Karafarin, Razi, Mellat, Moallem, Pasargad, Day, Mihan.

Volmanen et al (2014), in their study, reviewed the details by analytic hierarchy process to evaluate health insurance companies. The results showed that there were significant differences between the rankings of insurance companies and the proposed model had the ability to rank companies. Dickson et al (2014), in their study, reviewed determining the advertising strategy for organizations using AHP model for Nigerian insurance industry. The results showed that the companies developing advertising strategy should invest more in advertising, direct marketing, personal and public selling.

\section{Methodology}

In this study, by reviewing the literature and using the opinion of experts, 23 indicators consisting financial indicators and nonfinancial indicators and indicators of performance evaluation were selected for 17 companies from private insurance companies for the period of 2011 to 2014, and were ranked by TOPSIS. Figure 1 shows the model of decision.

\section{Defining variables and method of calcula- tion}

\subsection{Liquidity ratios}

It is obtained by comparing the current assets or its constituent items to current liabilities. The liquidity ratios include the current ratio and cash ratio (Amraei et al., 2014).

Current ratio $=($ current asset $) /($ current debt $)$ 
Cash ratio $=($ Cash + shortterm investment $) /($ current debt $)$

\subsection{Leverage ratios}

These ratios review and evaluate firms related used funds in terms of debt or equity and, and in fact determine their composition. The leverage ratios include debt ratio, the ratio of total debt to equity (Amraei et al., 2014).

Debt ratio $=($ total debt $) /($ total assets $)$

The ratio of equity to total assets $=($ equity $) /($ total assets $)$

Fixed asset to equity ratio $=($ Fixed asset $) /$ (equity $)$

Ratio of fixed assets to long-term debt= $($ Fixed asset $) /$ (longterm debt)

\subsection{The activity ratios (ratios of asset turnover)}

Activity ratios determine the extent to which the institution applies its resources effectively. These ratios are related to the comparison between sales volume and investments in different assets such as inventory, fixed assets, debtors, etc. These ratios include asset turnover ratio, turnover ratio of accounts receivable (sales equals to issued premium) (Amraei et al., 2014).

Turnover ratio of accounts receivable $=($ net sale $) /($ accounts receivable)

Current asset turnover $=($ net sale $) /($ curent assset $)$

Total asset turnover $=($ net sale $) /($ total asset $)$

\subsection{Profitability ratios}

Profitability ratios indicate the extent to which the institution is run efficiently and optimally. In fact, it measures corporate success in obtaining net return to sales revenue or to investments.

Net profit margin rate $=($ Profit after tax $) /$ sale

Rate of return on capital $=($ profit before tax $) /$ equity

Return of equity $(\mathrm{ROE})=($ net profit $) /($ equity $)$

Return on assets $(\mathrm{ROA})=($ net profit $) /($ Total assets $)$

\subsection{Growth rate}

Sales growth, operating profit growth, growth of equity and growth of assets are such ratios that we use:

Sales of premium $=($ curent year premium sale-last year premium sale)/(year premium sale)

Operating Profit Growth $=($ current year Operating Profit -last year Operating Profit)/ (last year Operating Profit)

Growth of Equity= (current year Equity-last year Equity)/ (last year Equity)

Growth of assets $=($ current year assets-last year assets $) /$ (last year assets)

\subsection{Market value added (MVA)}

According to this approach where economic concepts is used, business unit performance is evaluated with emphasis on profitability of assets and rate of return and the cost of capital employed (Anvari Rostami et al., 2006).
MVA =Book value of equity - the value of stock market Common stock value $=$ Stock price $\times$ number of stocks

\subsection{Economic value added (EVA)}

EVA is a measure that considers the opportunity cost of the resources used in the company. In other words, positive economic value represents the optimal allocation of resources, creation of value and increase in shareholder wealth in the company. In addition, negative economic value represents wasting, non-optimal and inefficient allocation of resources and consequently reduction of shareholder wealth. Economic value added is obtained from the following equation.

$\mathrm{EVA}=\mathrm{NOPAT}-\mathrm{IC} \times \mathrm{WACC}$

Where, NOPAT is Net operating profit after tax, WACC is Weighted average cost of capital, capital, IC is the value of investments by owners and creditors.

$\mathrm{IC}=$ the amount of investment that is equal to Net property of machinery, equipment + other assets + intangible assets + (current assets - current liabilities excluding financial liabilities) $=$ longterm debt + financial liabilities + other interest-bearing liabilities + regulatory capital + savings + retained earnings + staff redundancy payment reserves

$$
\mathrm{WACC}=\left(\mathrm{w}_{\mathrm{d}} \times \mathrm{K}_{\mathrm{d}}\right)+\left(\mathrm{w}_{\mathrm{e}} \times \mathrm{k}_{\mathrm{e}}\right)
$$

Weight of each resource is derived by dividing the amount of each source to sum of resources. It means sum of resources equals to total debt and equity and retained earnings

Wd: Total interest-bearing debt ratio on total resources

We: Equity and retained earnings divided by total resources

$\mathrm{Kd}$ and Ke Respectively shows the rate of cost of debt and equity.

\subsection{Refined economic value added: (REVA)}

Some groups believe in the calculation of EVA we can use market value rather than refined book value of assets; calculation are as follows:

REVA $=$ NOPATt $-($ WACC $*($ The market value of equity + debt market value))

Issued premiums: Includes direct and indirect premiums. Direct premiums are received by the insurance company or the branch and indirect premiums are related to insurances offered by the representatives of insurance companies brokers.

\section{Findings}

In the present study, using the Shannon entropy, insurance companies performance indicators were weighted (Asgharpour, 2014), and then were ranked using TOPSIS in terms of the predetermined criteria (Asgharpour, 2014). Weighting results indicated the priority of criteria using Shannon entropy weighting. According to Shannon entropy, weights of each financial, non-financial indicators and performance evaluations in the years 2011 to 2014 are specified in Table 1 to 3 . Based on the information obtained it can be said that in these years, any measure that had the greatest weight was more important in the same year ranking. In addition, the results of the ranking of insurance companies in the target years by TOPSIS Model are shown in Tables 4 to 6 .

\section{Conclusion and recommendations}

Results of Ranking of insurance companies using financial measures are shown in Table 4. As mentioned options that are more valuable in terms of criteria, have more chances to get higher 
ranking and more overall value in TOPSIS. Arman the insurance company has a good performance in terms of the criteria in 2011 and 2012. It ranked in the first place in 2011 and 2012. In the years 2013 and 2014, Kosar and Mihan insurance companies were at the first. On the other hand, in 2011, 2012 and 2014, and 2013 respectively Kosar, Day and Sina insurance Companies, ranked the last place. Ranking of other companies for the years 2011 to 2012 are shown in Table 4 and 5. Results of ranking of insurance companies using performance evaluation indexes are shown in Table 5. According to Table 5.5 Alborz insurance company has a good performance in terms of performance evaluation indexes in 2011 and 2013, and ranked 1st in 2011 and 2013. In the year 2012, Pasargad Insurance Company and in 2014, Parsian Insurance Company respectively ranked the first place. In contrast Razi Insurance in 2011, Day in 2012 and 2013 and in 2014 Novin insurance ranked last place. Ranking of other companies for the years 2011 to 2012 is shown in Table 5.5. Results of ranking of insurance companies using non-financial indicators are shown in Table 6. Using the results in Table 6 it can be said that based on non-financial criteria, premium issued, compensation and etc. Asia insurance company in in the years 2011 to 2014 has been the first. Dana Insurance Company in 2011, 2013 and 2014 ranked second and Alborz Insurance Company in 2011, 2013 and 2014 has been the third. In the period under review, based on non-financial indicators in 2011 and 2012 Kosar insurance was at last place; Razi, and Day insurance companies in the years 2013 and 2014 were the last.

Proper evaluation of overall company performance requires a comprehensive assessment of all the factors. Therefore, carrying out scientific studies in order to provide a comprehensive list of factors is necessary to develop appropriate methods of performance evaluation studies. According to the results, the following suggestions are offered.

It is suggested to directors 9 according to the weight of criteria, pay more attentions to the criteria that are given more weight and by planning improve company's' ranking.

It is recommended to investors to invest in insurance companies take note of the results of this research to select companies that perform better.

Given that the different criteria were used for ranking in this study, managers, investors and other stakeholders are suggested to use the results for decision making.

In addition, given that the different criteria were used for ranking it is recommended to weak companies in the industry to take necessary measures to improve their ranks. In addition, firms with higher status should make necessary decisions to protect their own position. All these factors led to the creation of a competitive environment in the industry, which ultimately leads to improved efficiency in the performance of insurance companies and will increase insurance services for customer.

As was observed large insurance companies like Asia, Iran, Alborz etc. had higher ranks just in indicators such as premiums issued and the number of employees with experience and etc. However, they had not high rankings on criteria such as performance evaluation and financial ratios. The reason for this is marginal costs of these companies, which is higher than other companies are. Therefore, it is recommended to these companies to make necessary decisions to improve their performance.

Table 1: Weight and Degree of Ultimate Importance of Financial Indicators

\begin{tabular}{lllll}
\hline \multirow{2}{*}{ Financial indicators } & \multicolumn{3}{c}{ The weight of indicators } \\
\cline { 2 - 5 } & 2011 & 2012 & 2013 & 2014 \\
\hline Current ratio & 0.121122 & 0.004142 & 0.004155 & 0.003032 \\
Cash ratio & 0.194752 & 0.034356 & 0.038559 & 0.034068 \\
Debt ratio & 0.005341 & 0.001938 & 0.006104 & 0.002052 \\
The ratio of equity to total assets & 0.017952 & 0.016601 & -0.078537 & 0.014691 \\
Fixed asset-to-equity ratio & 0.018633 & 0.021339 & 0.035269 & 0.016327 \\
Ratio of fixed assets to long-term debt & 0.071538 & 0.168225 & 0.104253 & 0.283777 \\
Accounts receivable turnover & 0.075628 & 0.199278 & 0.25137 & 0.124268 \\
Current asset turnover & 0.00837 & 0.010265 & 0.008144 & 0.006178 \\
Total assets turnover & 0.008846 & 0.007315 & 0.008765 & 0.004964 \\
Net profits margin rate & 0.213017 & 0.020761 & -0.033448 & 0.069496 \\
Sales growth & 0.122915 & 0.428879 & -0.023449 & 0.056277 \\
Operating Profit Growth & 0.153509 & -0.07752 & 0.107164 & 0.49525 \\
Growth of Equity & 0.010498 & 0.133749 & 0.586969 & -0.12497 \\
Growth of Asset & -0.022122 & 0.030675 & -0.015317 & 0.014586 \\
\hline
\end{tabular}

Table 2: Weight and Final Importance of Performance Evaluation Indexes

\begin{tabular}{lllll}
\hline \multirow{2}{*}{ Performance assessment indicators } & \multicolumn{3}{c}{ The weight of indicators } \\
\cline { 2 - 5 } & 2011 & 2012 & 2013 \\
\hline Return on capital & -0.10088 & 0.37053 & -0.51505 & -0.49933 \\
Return on Equity & -0.09641 & 0.427675 & 0.1636 & 0.001611 \\
ROA & -0.12471 & 0.029732 & 0.981725 & -0.73319 \\
MVA & 1.430075 & 0.152877 & 0.4750598 & 0.765838 \\
refined value added economic & -0.10808 & 0.019186 & 0.305814 & 1.765838 \\
\hline
\end{tabular}

Table 3: Weight and Final Importance of Non-Financial Indicators

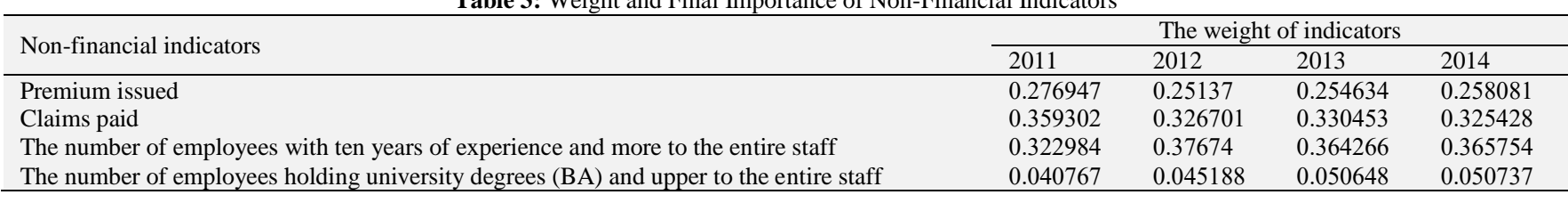

Table 4: The Results of the Ranking of Insurance Companies Based on Financial Indicators

\begin{tabular}{|c|c|c|c|c|}
\hline Rank & 2011 & 2012 & 2013 & 2014 \\
\hline 1 & Arman Insurance & Arman Insurance & Mihan Insurance & Kosar Insurance \\
\hline 2 & Parsian Insurance & Mihan Insurance & Razi Insurance & Mihan Insurance \\
\hline 3 & Kosar Insurance & Hafez Insurance & Ma Insurance & Hafez Insurance \\
\hline 5 & Day insurance & Alborz Insurance & Arman Insurance & Arman Insurance \\
\hline 6 & Hafez Insurance & Asia Insurance & Pasargad Insurance & Asia Insurance \\
\hline 7 & Karafarin Insurance & Day insurance & Hafez Insurance & Pasargad Insurance \\
\hline
\end{tabular}




\begin{tabular}{|c|c|c|c|c|}
\hline 8 & Sina Insurance & Karafarin Insurance & Parsian Insurance & Alborz Insurance \\
\hline 9 & Pasargad Insurance & Saman Insurance & Karafarin Insurance & Parsian Insurance \\
\hline 10 & Ma Insurance & Novin insurance & Kosar Insurance & Ma Insurance \\
\hline 11 & Saman Insurance & Razi Insurance & Saman Insurance & Day insurance \\
\hline 12 & Asia Insurance & Pasargad Insurance & Dana insurance & Mellat insurance \\
\hline 13 & Alborz Insurance & Mellat insurance & Alborz Insurance & Novin insurance \\
\hline 14 & Dana insurance & Parsian Insurance & Asia Insurance & Dana insurance \\
\hline 15 & Novin insurance & Sina Insurance & Mellat insurance & Saman Insurance \\
\hline 16 & Razi Insurance & Ma Insurance & Sina Insurance & Razi Insurance \\
\hline
\end{tabular}

Table 5: Results of the Ranking of Insurance Companies Based on Performance Evaluation Indexes

\begin{tabular}{|c|c|c|c|c|}
\hline Rank & 2011 & 2012 & 2013 & 2014 \\
\hline 1 & Alborz Insurance & Parsian Insurance & Alborz Insurance & Pasargad Insurance \\
\hline 2 & Day insurance & Pasargad Insurance & Mellat insurance & Day insurance \\
\hline 3 & Asia Insurance & Ma Insurance & Novin insurance & Kosar Insurance \\
\hline 4 & Pasargad Insurance & Kosar Insurance & Kosar Insurance & Parsian Insurance \\
\hline 5 & Arman Insurance & Sina Insurance & Parsian Insurance & Arman Insurance \\
\hline 6 & Parsian Insurance & Saman Insurance & Ma Insurance & Ma Insurance \\
\hline 7 & Dana insurance & Novin insurance & Saman Insurance & Mellat insurance \\
\hline 8 & Novin insurance & Mellat insurance & Pasargad Insurance & Alborz Insurance \\
\hline 10 & Saman Insurance & Karafarin Insurance & Arman Insurance & Mihan Insurance \\
\hline 11 & Mihan Insurance & Mihan Insurance & Hafez Insurance & Hafez Insurance \\
\hline 12 & Hafez Insurance & Arman Insurance & Mihan Insurance & Karafarin Insurance \\
\hline 13 & Mellat insurance & Alborz Insurance & Sina Insurance & Dana insurance \\
\hline 14 & Kosar Insurance & Asia Insurance & Asia Insurance & Razi Insurance \\
\hline 15 & Sina Insurance & Dana insurance & Razi Insurance & Saman Insurance \\
\hline 16 & Karafarin Insurance & Razi Insurance & Dana insurance & Sina Insurance \\
\hline 17 & Razi Insurance & Day insurance & Day insurance & Novin insurance \\
\hline
\end{tabular}

Table 6: The Results of the Ranking of Insurance Companies Based on Non-Financial Indicators

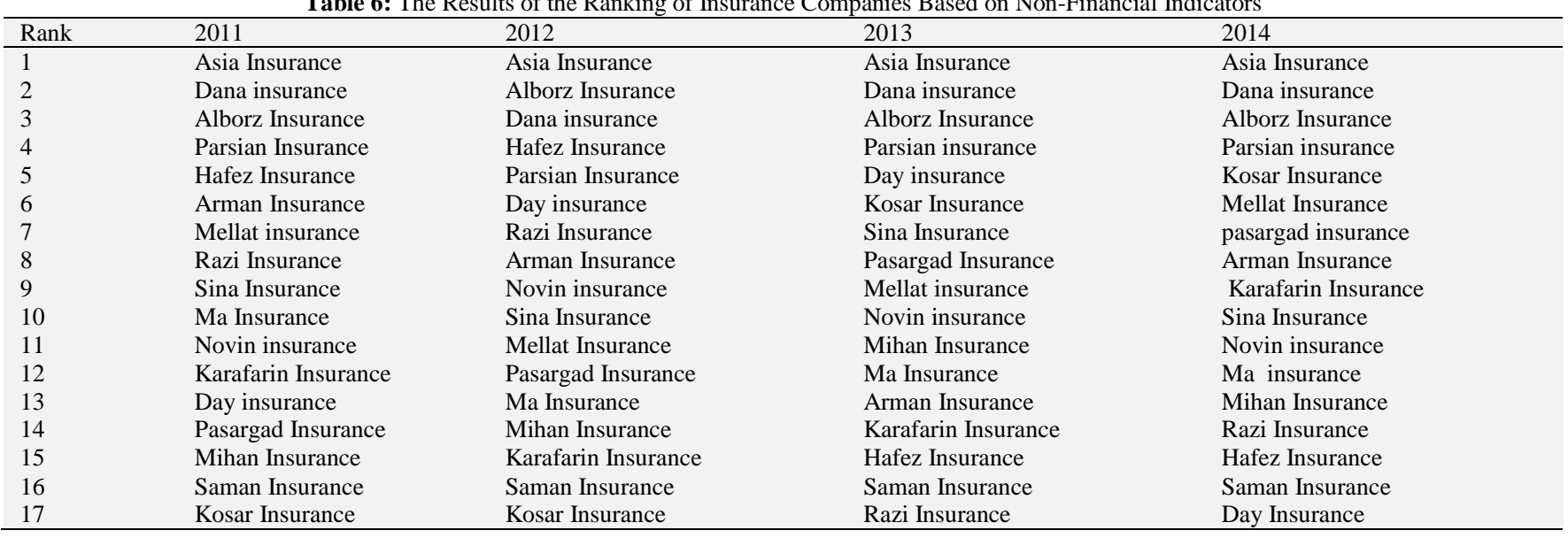

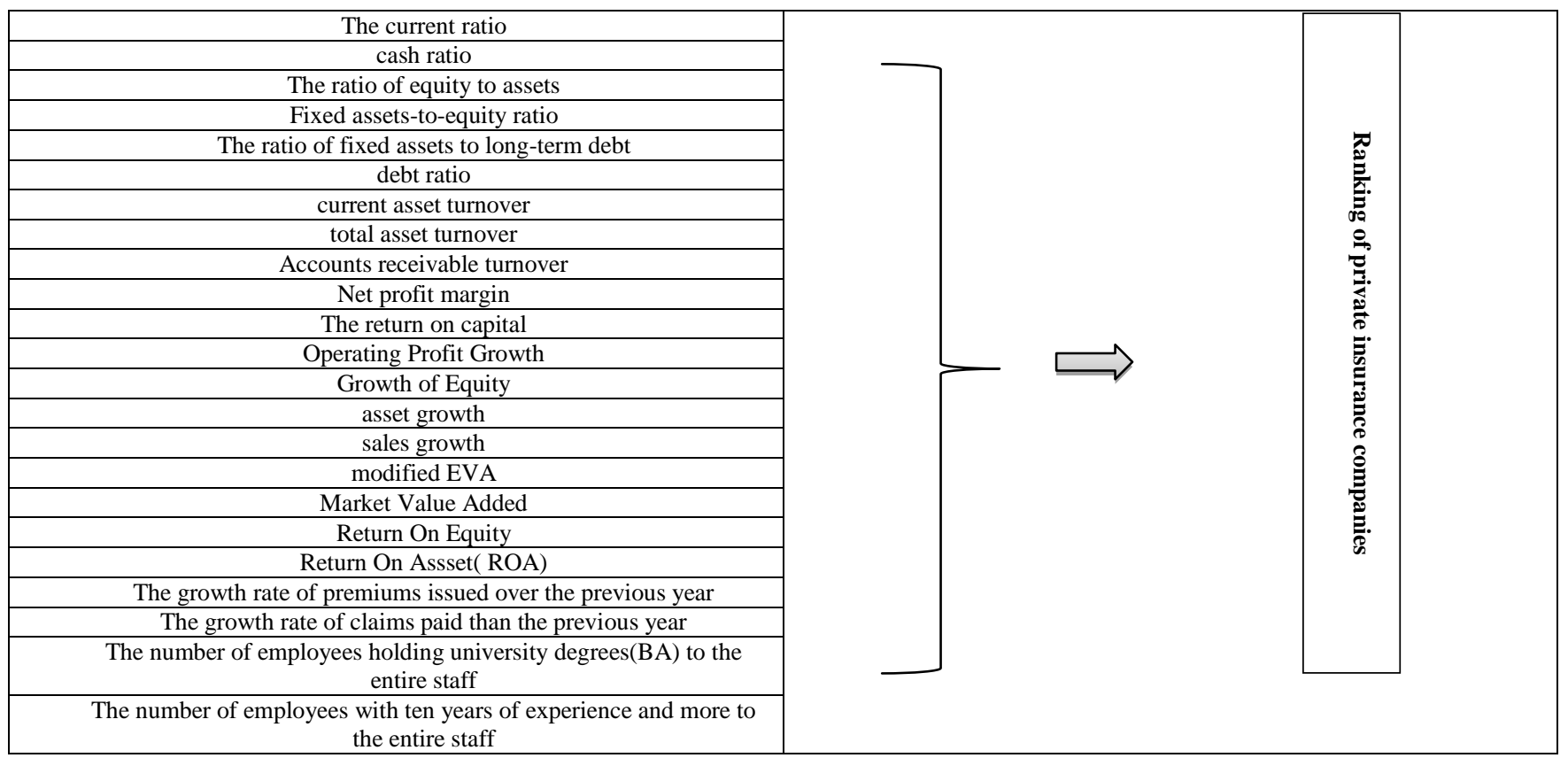

Fig. 1: Conceptual Model of Research (Amraei Et Al., 2014 and Nemati and Kazemi, 2014). 


\section{References}

[1] Nemati, Muhammad and Kazemi, Aaliyeh (2014), the ranking of insurance companies using Multi Attribute Decision Making, Financial Research, Volume 16, Issue 1.

[2] Dehkordi, Mehdi, (2014), review and ranking of the factors affecting the financial performance of the insurance industry with (DEA / MADM), Master Thesis, University of Science and Art.

[3] Mazloumi. Nader, Dadvand. Sara, (2012) identifying and ranking the factors affecting competitive advantage of insurance companies, Insurance Journal, Volume 27, Issue 2.

[4] Amraei. Parviz, Zarif. Somayeh and Mousavi. Hamid, 2014, evaluating performance and ranking of companies in the cement industry in Tehran Stock Exchange using FAHP and TOPSIS, International Management Conference, Tehran, Institute of Mobin cultural ambassadors (SAFIRAN E FARHANGI E MOBIN)

[5] Alvani, S. (2010), Public administration. Tehran: Ney Publications.

[6] Hassanzadeh, H. Zare, P. (2009) explaining the performance evaluation indexes of private insurance companies using the BSC by experts, Quarterly of insurance industry, Insurance institution, No. 23.

[7] Mirzaee, H and Safari. A, (2009), Introduction to ranking Iranian insurance companies, Insurance World News, No, 136 and 137, p. 16.

[8] Parizadi, Isa (2009), financial ratios and economic variables of assessing the financial health and stability of insurance companies in Iran, master's thesis, Allameh Tabatabaei University.

[9] Soleimani, Zahra (2011) comparative analysis of ranking of insurance companies using RBC and CAMEL models, a master's thesis.

[10] Asgharpour, M., (2014), Multi Criteria Discussion Making (MCDM), Tehran University Press, First Edition, Page 214

[11] Hosseini. Seyed Hassan, Ezazi. Mohammad Ismail, Donyayi. Mohammad, Tehrani. Reza, (2011) "Comparison of Top ranking companies based on financial ratios with hybrid approach of AHP TOPSIS and indicators of Tehran Stock Exchange" Journal of Financial Engineering and Management in Tehran, No. VIII, autumn.

[12] Anvari Rostami. Ali Asghar and Khotanlou. Mohsen, (2006), the scale of ranking the top companies based on profitability ratios and indicators of Tehran Stock Exchange, accounting and audit investigations, No. 43, PP. 25-43.

[13] Saeed Sehhat, Mahsa Taheri, Davoud Hosseinabadi Sadeh. Ranking of insurance companies in Iran using AHP and TOPSIS techniques. American Journal of Research Communication, 2015, 3(1): 51-60\}

[14] Akhisar, Ilyas and Tunay, Necla (2015), Performance Ranking of Turkish Life Insurance Companies Using AHP and TOPSIS, management international conference, Slovenia.

[15] Dewey Wollmanna, Maria Teresinha Arns Steiner, Guilherme Ernani Vieira, Patrícia Arns Steiner, (2014), Details of the analytic hierarchy process echnique for the evaluation of health insurance companies, Production, v. 24, n. 3, p. 583-593, July/Sept. 2014

[16] Bolajoko Nkemdinim Dixon-Ogbechi, Sikuade Oladimeji Jagun, Salome Ogheneochuko Ighomereho, Ganiyu Ajao Rahim, Elizabeth Marie Haran, (2014), DETERMINATION OF PROMOTIONAL STRATEGY FOR ORGANIZATIONS IN THE NIGERIAN INSURANCE INDUSTRY USING THE AHP MODEL, http://dx.doi.org/10.13033/ijahp.v7i1.261.

[17] Khodaei, Mohammad, Valahzaghard, and Ferdousnejhad, Mahnaz, (2013), ranking insurance firms using AHP and Factor Analysis, Management Science Letters 3 (2013) 937-942.on Internet. Patient Education and Counseling 53, 309-313. http://dx.doi.org/10.5267/j.msl.2013.01.027. 